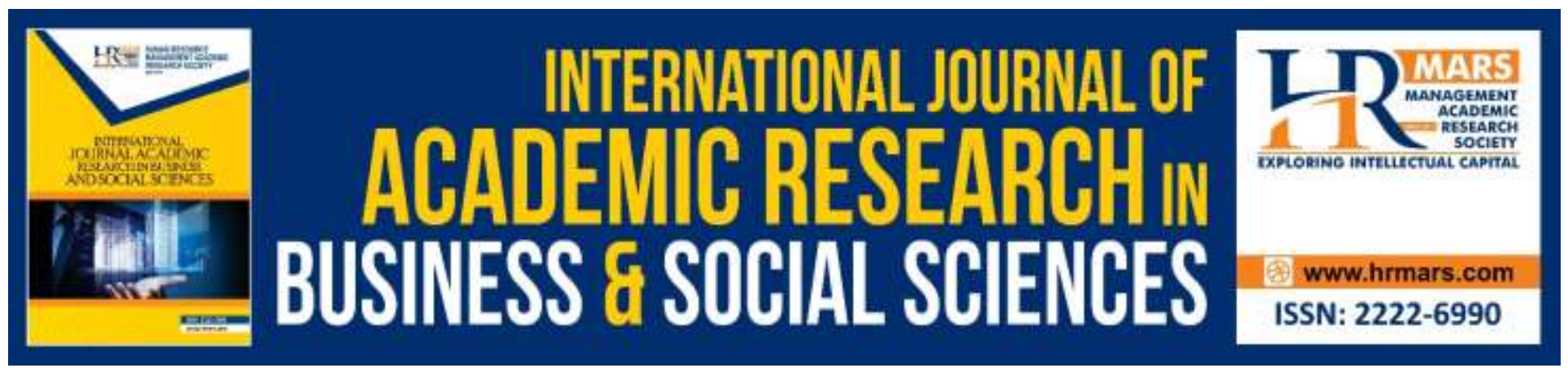

\title{
Exploring Students' Intentions towards Game-Based Learning in Statistics
}

\author{
Nur Izzah Binti Jamil, Alia Nadira Rosle, Farrah Nadia Baharuddin, Siti Sara \\ Ibrahim, Syazliana Kasim
}

To Link this Article: http://dx.doi.org/10.6007/IJARBSS/v9-i13/6255

DOI: $10.6007 /$ IJARBSS/v9-i13/6255

Received: 20 March 2019, Revised: 10 June 2019, Accepted: 29 July 2019

Published Online: 20 August 2019

In-Text Citation: (Jamil, Rosle, Baharuddin, Ibrahim, \& Kasim, 2019)

To Cite this Article: Jamil, N. I. B., Rosle, A. N., Baharuddin, F. N., Ibrahim, S. S., \& Kasim, S. (2019). Exploring Students' Intentions towards Game-Based Learning in Statistics. International Journal of Academic Research in Business and Social Sciences, 9(13), 196-205.

\section{Copyright: @ 2019 The Author(s)}

Published by Human Resource Management Academic Research Society (www.hrmars.com)

This article is published under the Creative Commons Attribution (CC BY 4.0) license. Anyone may reproduce, distribute, translate and create derivative works of this article (for both commercial and non-commercial purposes), subject to full attribution to the original publication and authors. The full terms of this license may be seen

at: http://creativecommons.org/licences/by/4.0/legalcode

Special Issue: Revolutionizing Education: Challenges, Innovation, Collaboration, 2019, Pg. 196 - 205 http://hrmars.com/index.php/pages/detail/IJARBSS

JOURNAL HOMEPAGE

Full Terms \& Conditions of access and use can be found at http://hrmars.com/index.php/pages/detail/publication-ethics 


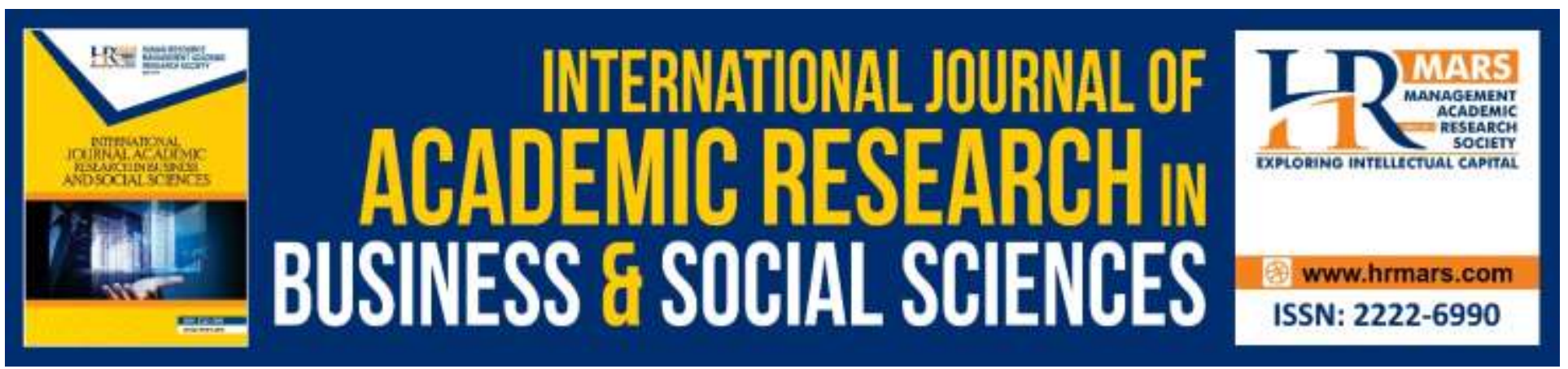

\title{
Exploring Students' Intentions towards Game-Based Learning in Statistics
}

\author{
Nur Izzah Binti Jamil ${ }^{1}$, Alia Nadira Rosle ${ }^{1}$, Farrah Nadia \\ Baharuddin $^{2}$, Siti Sara Ibrahim², Syazliana Kasim² \\ ${ }^{1}$ Faculty Computer and Mathematical Sciences, Universiti Teknologi MARA, Cawangan Negeri \\ Sembilan, Kampus Rembau, 71300 Rembau, Negeri Sembilan, Malaysia \\ Email: nurizzah@uitm.edu.my, aliarosle@uitm.edu.my \\ ${ }^{2}$ Faculty of Business and Management, Universiti Teknologi MARA, Cawangan Negeri Sembilan, \\ Kampus Rembau, 71300 Rembau, Negeri Sembilan, Malaysia \\ Email: farrahnadia@uitm.edu.my, saraibrahim@uitm.edu.my, syazliana@uitm.edu.my
}

\begin{abstract}
Game based learning has been used as a learning tool for centuries. This study proposes a development of game-based learning in Statistics subject. The game is a 2D prototype and the game is tested and adjusted to be more effective learning tool for learning. Statistics subject has been used for this study, known as a dreaded subject that causes many negative perceptions as students tend to think that learning Statistics is difficult. Premised on this concern, educators should create potential teaching and learning tool as a vector to challenges the perceived difficulty of learning statistics as well engage the learners and help educators access the learning. The aims of this study are to explore students' gain of using this teaching and learning tool in Statistics for classroom session and identify the factors affect their intention to use it. A total of 195 students were involved in this study using direct questionnaire and statistically observation through pre and post-test on their statistics test. It is reported that the tests of normality on the distribution for the pre marks with $(\mathrm{KS}=0.153, \mathrm{SW}=0.960, \mathrm{p}$-value $=0.00<0.05)$ and post marks with $(\mathrm{KS}=0.122, \mathrm{SW}=0.969, \mathrm{p}$ value $=0.00<0.005$ ) both were significantly not normal. Thus, Wilcoxon signed ranks test shows that there is a difference in pre and post score test. This preliminary study shows that there is an improvement in score after students used this teaching and learning tool. Multiple linear regression analysis show that students' intentions to use is significantly influenced by perceived usefulness $(t=2.781, p$-value $=0.000)$, perceived ease to use $(t=5.949, p$-value $=0.000)$ and attitude towards innovation ( $\mathrm{t}=8.545, \mathrm{p}$-value $=0.000$ ). In terms of importance, predictor attitude towards innovation made the largest contribution to the model (Standardized coefficient $=0.457$ ).
\end{abstract}

Keywords: Innovation, Education, Statistics, Non parametric, Multiple linear regression, TAM Model 


\section{Introduction}

As education becomes even more extensive to evolve the next generation, Statistic subject historically has been viewed by many students as difficult and unpleasant to learn, and by many instructors as frustrating and unrewarding to teach. This leads to a negative perception toward this subject which creates a challenge to the educator to effectively teach as well as the students to score the subject even though more and more students enroll in introductory Statistics courses. (Dani, Joan, 2004) and (Slootmaeckers, Kerremans, Adriaensen, 2014). In fact, this subject is widely used in almost all fields like Business Management, Biology, Botany, Commerce, Medicine, Education, Physics, Chemistry, Bio-Technology, Psychology, Zoology etc

Responding to this issue, case study is done to introduce a prototype tool in learning Statistic, in which to become more attractive, interesting and easy to understand for a student to score. Thus, it is important for the students and educators to put in place an innovation tools in their learning process. It is parallel with the aims of this study, which are to explore students' gain of using this innovative teaching and learning tool in Statistics subject for classroom session and identify factors that might affect their intention to use it. Students will have fun with the game and at the same time will allow educators to monitor and be change to suit them. In line with TAM (Technology Acceptance Model)'s, the level of student's intention to use the proposed innovative tools in learning Statistic subject were modelled on TAM's two core constructs; perceived usefulness and perceived ease to use. (Briz-Ponce, Pereira, Carvalho, 2017). Then, additional construct of attitude towards innovation is highlighted to expand the establish model. A session of observation is done through a questionnaire distribute to the students who are taking Statistic subject, having pre-test and post-test session to ideally measure the impact of learning Statistic subject before and after the new innovative teaching and learning tools to be in place.

The study begins with a brief overview of the understanding perceived usefulness and perceived ease to use as well as understanding attitudes towards innovation which at the end will affect student's intention to uses the proposed innovative tools in learning Statistic. Finally, the study is aimed to establish an innovative session of learning Statistic subject which previously having negative and difficult perceptions among students and educators in which it is proven that by having these tools, the learning process will become more attractive and easy to use by the students which in return, the positive result is displayed.

\section{Literature Review}

\section{Perceived Usefulness and Perceived Ease to Use}

The study has been applied the concept of technology acceptance model (TAM) which introduced by Davis (1989). The TAM model highlights the uses of perceived usefulness as well as perceived ease of use as the key constructs. Venkatesh and Davis (2000) had proposed an extended model of TAM 2 which is tested by using longitudinal data from four different systems at four organizations. Then, Venkatesh and Bala (2008) has proposed TAM 3 which regarding to expanding number of determinants that affect perceived usefulness and perceived ease of use of an innovation.

Perceived usefulness is defined as the degree to which a person believes that by using a specific system will enhance job performance. As such, it means that a person advantageously using any particular medium to increase his or her job performance. In an organizational context, good 
performances are being reinforced by promotions, bonuses, raises and other rewards (Pfeffer, 1982; Schein, 1980; Vroom, 1964).

Meanwhile, perceived ease to use defined as the degree to which a person believes that by using a specific system will set free for effort. As such, it means that freedom from difficulty will ease the process of achieving performance. According to Liaw and Huang (2007), the one element that improves e-learning success and outcomes are based on the useful environment characteristics such as interactive learning environment to create a high level communicative e-learning that allows learner to share information as well as to retrieve useful information. It has improved learners' positive attitude of behavioral intentions on e-learning.

\section{TAM Innovation Tools}

Perceived usefulness and perceived ease to use were significantly correlated with the usage in information technologies such as email (Davis, 1989). In addition to that, study shows that perceived usefulness mediates the effect on perceived ease to use on the usage in information technologies. According to Davis, Bagozzi and Warshaw (1989), they mentioned that the Technology Acceptance Model (TAM) is being developed from the Theory of Reasoned Action (TRA) in order to describe an individual acceptance behavior towards information technology. The theory suggested that two attitudes will influence behavioral intention in using a technology, namely, perceived usefulness and perceived ease of use.

Furthermore, both perceived usefulness and perceived ease to use play a role in predicting user's attitudes towards using a system (Davis, 1993). It stated that the influence of perceived usefulness was $50 \%$ stringer than perceived ease of use. It has been used to describe or predict behavioral intention in technologies, namely, e-commerce, e-library, e-banking, e-tax filing, word processing, social networking, smartcard as well as microcomputer (Deng, Doll, Hendrickson and Scazzero, 2005). According to (Elkaseh, Wong, \& Fung, 2016), both perceived of use and perceived usefulness of social networking media are the elements of the key factors in assessing students as well as teachers behavioral intention in using e-learning in higher education. The result stated that the use of social networking plays an important role in adoption of e-learning in higher education. Hence, when the social networking media is simple and easy to use, individual who feels that social media is more useful will have more intention to use e-learning technology for learning.

\section{Attitude towards Innovation by Educators}

Educator's willingness is the key factor in implementing new instructional practices and educational improvement (Ghaith \& Yaghi, 1997). It requires minor changes in the classroom activities, new curriculum as well as a very different instructional approach. The degree of educators' willingness toward innovation is depending on educators' present practices (congruence), the extra time needed and the effort to implement innovation (Doyle \& Ponder, 1977).

However, the analysis of the study stated teachers were willing to implement instructional practices that are similar to their current practices and less costly (Mohlman, Coladarci, and Gage, 1982). It has been supported by Sparks (1983), mentioned that teachers' perceptions of the importance of the new practices were positively correlated with the implementation; meanwhile, teachers' ratings of the difficulty of implementation were found to be highly individualistic and unrelated to the willingness to implement new practices. Thus, positive perceptions towards 
technology and an autonomous learning mode will influence students' attitude and satisfaction in a flexible learning (Drennan, Kennedy \& Pisarski, 2005). It has been influenced by the perceived usefulness of flexible learning and by the learner's locus of control. At the beginning of the course, perceived usefulness and locus of control were significantly related to the course satisfaction.

\section{Attitude towards Innovation by Students}

Meanwhile, an innovative attitude of students was directly related to perceived usefulness of flexible learning. That finding suggests that those students who were willing to try new approaches and take risks were more likely to view the technology positively and perceive higher usefulness (Drennan, Kennedy \& Pisarski, 2005). Students' orientation towards information, communication as well as technology were reflected to the relevancy of using information technology in employment instead of their needs for social connection and leisure use of technologies (Edmunds, Thorpe, $\&$ Conole, 2012). It has been positively motivated toward technologies that are relevant to their future employment intentions.

\section{Methodology}

\section{Response Rate and Completion Rate}

A research survey is often the best and fastest way to acquiring people knowledge and information. Furthermore, the quality of data collected in research survey is commonly indicated by both response and completion rate which are viewed as important indicators of measuring research survey quality. According to Jack (2008), response rates approximating $60 \%$ for most research should be the goal of researchers. Response rate is quite different compare to completion rate. Below shows the illustration for both response rate (Eq. 1) and completion rate (Eq. 2) and it is usually expressed in the form of a percentage.

$\begin{array}{lll}\mathrm{x} & = & \text { Survey out } \\ \mathrm{y} & = & \text { Number of respondents who participated the survey } \\ \mathrm{z} & = & \text { Number of respondents who completed the survey }\end{array}$
Response rate $=\frac{z}{x} \times 100$
Completion rate $=\frac{z}{y} \times 100$

\section{Reliability Analysis}

Cronbach's alpha is the most common measure of internal consistency in order to determine if the scale is reliable. It is most commonly used when researcher use multiple Likert scales in a questionnaire. This study devised a 10 Likert scales from "strongly disagree" to "strongly agree".

\section{Research Objectives}

There are two objectives in this study; 
INTERNATIONAL JOURNAL OF ACADEMIC RESEARCH IN BUSINESS AND SOCIAL SCIENCES

Vol. 9, No. 13, Special Issue: Revolutionizing Education: Challenges, Innovation, Collaboration., 2019, E-ISSN: 2222-6990 @ 2019 HRMARS

Table 1. Research Objectives

No. Research Objectives

Requirements

- Normality test

to explore students' gain of using this teaching

1. and learning tool in Statistics course

- Comparing means of variables for two dependent samples (Pre and Post)

Ho: There is no change

$\mathrm{Hi}$ : There is change

Multiple Linear Regression

- Error is independent, identically normally distributed with zero

2. to identify factors that might affect students' mean and constant variance.

intentions to use it.

- There is a linear relationship between dependent variable (y) and independent variable $(\mathrm{x})$.

- No Multicollinearity problem (VIF $<10$ \& Tolerance $>0.10$ )

\section{Analysis and Findings}

A total of 210 questionnaires were sent and 195 students completed the questionnaire in this study from a total of 7 groups. Both response and completion rate are high (RR=92.86\%) and (CR=94.20\%) respectively. It is viewed as important indicators of measuring survey quality.

Table 2. Response Rate and Completion Rate

\begin{tabular}{lc}
\hline & Total \\
\hline Survey sent & 210 \\
Number of students who participated the survey & 207 \\
Number of students who completed the survey & 195 \\
\hline Response rate & $\frac{195}{210} \times 100=92.86 \%$ \\
\hline Completion rate & $\frac{195}{207} \times 100=94.20 \%$ \\
\hline
\end{tabular}

Reliability analysis using Cronbach's alpha of 0.704 for all variables included in this study showed the score is acceptable. Tests of normality on the distribution for the pre marks with $(\mathrm{KS}=0.153, \mathrm{SW}=0.960, \mathrm{p}$-value $=0.00<0.05)$ and post marks with $(\mathrm{KS}=0.122, \mathrm{SW}=0.969, \mathrm{p}$ value $=0.00<0.005$ ) both were significantly not normal. Thus, nonparametric test was applied for the means comparison of variable marks between two dependent groups (pre and post). 
INTERNATIONAL JOURNAL OF ACADEMIC RESEARCH IN BUSINESS AND SOCIAL SCIENCES

Vol. 9, No. 13, Special Issue: Revolutionizing Education: Challenges, Innovation, Collaboration., 2019, E-ISSN: 2222-6990 @ 2019 HRMARS

Table 3. Test of Normality

\begin{tabular}{lcccccc}
\hline Normality test & \multicolumn{3}{c}{ Kolmogorov-Smirnov } & \multicolumn{3}{c}{ Shapiro-Wilk } \\
\hline Variable & Statistic & df & p-value & Statistic & df & p-value \\
\hline Pre marks & 0.153 & 195 & 0.000 & 0.960 & 195 & 0.000 \\
Post marks & 0.122 & 195 & 0.000 & 0.969 & 195 & 0.000 \\
\hline
\end{tabular}

Out of 195 students, 185 students perform better in their statistics score, only 4 students did not perform better and 6 students did not show any improvement in their statistics score. Based on positive ranks, Wilcoxon signed ranks test shows that there is a different in pre and post score test. This provides overall finding that there is an improvement in score after students used this teaching and learning tool.

Table 4. Wilcoxon Signed Ranks Test (Nonparametric test)

\begin{tabular}{ccc}
\hline Test Statistics & $\mathbf{N}$ & Interpretation \\
\hline Negative ranks & 185 & Post marks $>$ Pre marks \\
Positive ranks & 4 & Pre marks $>$ Post marks \\
Ties & 6 & Post marks = Pre marks \\
\hline Wilcoxon Signed Ranks & -11.892, & There is change in score \\
Test, $p$-value & p-value $=0.000<0.05$ & \\
\hline
\end{tabular}

The next attached figure is to identify factors that may affect students' intentions towards innovation in learning Statistics using this teaching and learning tool by implementing multiple linear regressions.

Table 5. Variables included in the model

\begin{tabular}{cc}
\hline Variable & Role of Variable \\
\hline Intention to use & Dependent variable, $\mathrm{y}$ \\
Perceived usefulness & Independent variable, $\mathrm{x}_{1}$ \\
Perceived ease to use & Independent variable, $\mathrm{x}_{2}$ \\
Attitude towards innovation & Independent variable, $\mathrm{x}_{3}$ \\
\hline
\end{tabular}

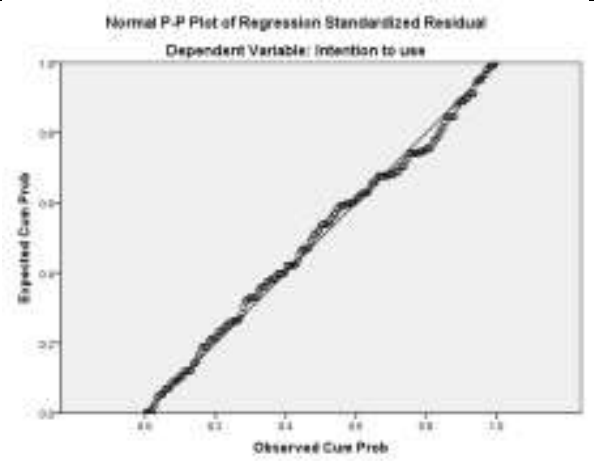

Fig. 1 Normal P-P Plot of Regression Standardized Residual 


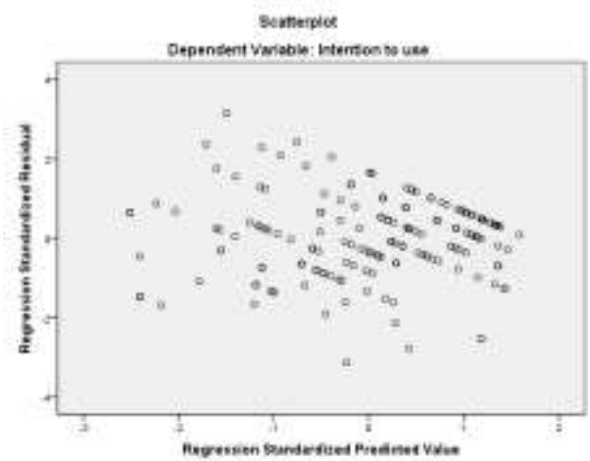

Fig. 2 Scatter plot

The normal probability plot shows that the residuals are normally distributed (Fig. 1). Figure 2 shows the scatter plot of regression standardized predicted value versus regression standardized residual; there is a random pattern in scatter plot which indicates the residuals have constant variance, independent of each other and linearly related. No outlier exists in the scatter plot since there is no point exceeds 3.3 or less than -3.3. This satisfies the assumption of zero mean.

The ANOVA table shows the regression model is fit with $F=64.09, p$-value $=0.000<0.05$. $R$ square of 0.502 indicates the regression model with all independent variables included in the model can explain only $50.20 \%$ of the variation in dependent variable; intention to use. Another $49.80 \%$ is explained by other independent variable. Future research suggested to adding more independent variables and increasing the sample size.

Table 6. Analysis of Variance

\begin{tabular}{lccccc}
\hline Model & SS & df & MS & F & p-value \\
\hline Regression & 84.385 & 3 & 28.128 & 64.090 & .000 \\
Residual & 83.828 & 191 & .439 & & \\
Total & 168.213 & 194 & & & \\
\hline
\end{tabular}

$R$ value $=0.708, R-$ Square $=0.502$

All Tolerance values are more than 0.10 and VIF values are less than 10, indicates there is no multicollinearity problem (Table 7). Multiple linear regression analysis show that students' intentions to use is significantly influenced by perceived usefulness ( $t=2.781, p$-value $=0.000$ ), perceived ease to use $(t=5.949, p$-value $=0.000)$ and attitude towards innovation $(t=8.545, p$-value $=0.000)$. In terms of importance, independent variable of attitude towards innovation made the largest contribution to the model (Standardized coefficient $=0.457$ ). The suggested model for this study is shown below (Eq. $3)$ : 
INTERNATIONAL JOURNAL OF ACADEMIC RESEARCH IN BUSINESS AND SOCIAL SCIENCES

Vol. 9, No. 13, Special Issue: Revolutionizing Education: Challenges, Innovation, Collaboration., 2019, E-ISSN: 2222-6990 @ 2019 HRMARS

Table 7. Table of Coefficients

\begin{tabular}{|c|c|c|c|c|c|c|}
\hline \multirow{2}{*}{ Model } & \multirow{2}{*}{ B } & \multirow{2}{*}{ Beta } & \multirow{2}{*}{$\mathrm{t}$} & \multirow{2}{*}{$\mathrm{p}$-value } & \multicolumn{2}{|c|}{ Collinearity Statistics } \\
\hline & & & & & Tolerance & VIF \\
\hline Constant & 1.687 & & & & & \\
\hline Attitude towards innovation & 0.414 & 0.457 & 8.545 & 0.000 & 0.912 & 1.097 \\
\hline Perceived ease to use & 0.305 & 0.337 & 5.949 & 0.000 & 0.814 & 1.229 \\
\hline Perceived usefulness & 0.111 & 0.156 & 2.781 & 0.006 & 0.834 & 1.199 \\
\hline
\end{tabular}

$$
\begin{aligned}
& y=B_{0}+B_{1} x_{1}+B_{2} x_{2}+B_{3} x_{3} \\
& y=1.687+0.414 x_{1}+0.305 x_{2}+0.111 x_{3}
\end{aligned}
$$

\section{Conclusion}

Pertaining to the aims of this study, to explore students' gain of using this teaching and learning tool in Statistics course for classroom session and to identify factors that might affect their intention to use it, Wilcoxon signed ranks test shows that there is a different in pre and post score test which indicates that there is an improvement in score after students used this teaching and learning tool. This suggests that this teaching and learning tool matched student's interests and were conducive for their motivation and enjoyment of the learning session. As regards the multiple linear regression analysis, factors that might affect students' intentions to use is significantly influenced by perceived usefulness ( $t=2.781, p$-value $=0.000)$, perceived ease to use $(t=5.949, p$-value $=0.000)$ and attitude towards innovation ( $\mathrm{t}=8.545, \mathrm{p}$-value=0.000). Note that all independent variables having positive relationship with the dependent variables (students' intentions to use). In terms of importance, predictor attitude towards innovation made the largest contribution to the model (Standardized coefficient $=0.457$ ). It is important to have an innovative attitude among next-gen as a fresh approach to problems and they must bear willingness to be open to grasp multidisciplinary in life and work. Educators and students are expected to innovate the theory and practice of teaching and learning because the need for educational innovations has become keen and it is believed that countries' social and economic well-being will depend on the quality of education.

\section{Acknowledgement}

This work was supported by Institute of Research Management and Innovation (IRMI), Universiti Teknologi MARA under Academic \& Research Assimilation (ARAS) Grant No 600-IRMI/DANA 5/3/ARAS (0169/2016) and also Universiti Teknologi MARA Cawangan Negeri Sembilan.

\section{References}

Dani, B. Z., \& Joan, G. (2004). Statistical literacy, reasoning, and thinking: Goals, definitions, and challenges. In The challenge of developing statistical literacy, reasoning and thinking (pp. 3-15). Springer, Dordrecht.

Doyle, W., \& Ponder, G. (1977). The practicality ethic and teacher decision-making. Interchange, 8, 112.

Drennan, J., Kennedy, J., \& Pisarski, A. (2005). Factors affecting student attitudes toward flexible 
INTERNATIONAL JOURNAL OF ACADEMIC RESEARCH IN BUSINESS AND SOCIAL SCIENCES

Vol. 9, No. 13, Special Issue: Revolutionizing Education: Challenges, Innovation, Collaboration., 2019, E-ISSN: 2222-6990 @ 2019 HRMARS

online learning in management education. The Journal of Educational Research, 98(6), 331-338.

Edmunds, R., Thorpe, M., \& Conole, G. (2012). Student attitudes towards and use of ICT in course study, work and social activity: a technology acceptance model approach. British Journal of Educational Technology, 43(1), 71-84.

Elkaseh, A. M., Wong, K. W., \& Fung, C. C. (2016). Perceived Ease of Use and Perceived Usefulness of Social Media for e-Learning in Libyan Higher Education: A Structural Equation Modeling Analysis. International Journal of Information and Education Technology, 6(3), 192-199. http://doi.org/10.7763/IJIET.2016.V6.683

Ghaith, G., \& Yaghi, H. (1997). Relationships among experience, teacher efficacy, and attitudes toward the implementation of instructional innovation. Teaching and Teacher Education, 13(4), 451-458.

Ifinedo, P. (2017). Examining students' intention to continue using blogs for learning: Perspectives from technology acceptance, motivational, and social-cognitive frameworks. Computers in Human Behavior, 72, 189-199.

Jack, E. F. (2008). Response Rates and Responsiveness for Surveys, Standards and the Journal. American Journal of Pharmaceutical Education, 72(2), 43.

Liaw, S. S., \& Huang, H. M. (2007). Developing a collaborative e-learning system based on users' perceptions. Lecture Notes in Computer Science, 4402, 751-759.

Mohlman, G., Coladarci, T. \& Gage, N. (1982). Comprehension attitudes as predictors of implementation of teacher training. Journal of Teacher Education, 23(1), 31-36.

Peter Serdyukov, (2017) "Innovation in education: what works, what doesn't, and what to do about it?"Journal of Research in Innovative Teaching \& Learning, Vol. 10 Issue: 1, pp.4-33, https:// doi.org/10.1108/JRIT-10-2016-0007

Pfeffer, J. (1982). Organizations and Organization Theory, Pitman, Boston, MA, 1982. Schein, E.H. Organizational Psychology, third edition, Prentice-Hall, Englewood Cliffs, NJ, 1980.

Slootmaeckers, K., Kerremans, B., \& Adriaensen, J. (2014). Too afraid to learn: Attitudes towards statistics as a barrier to learning statistics and to acquiring quantitative skills. Politics, 34(2), 191200.

Sparks, G. N. (1983). Synthesis of research on staff development for effective teaching. Educational Leadership, 41(3), 65-72.

Venkatesh, V., and Davis, F. D. (2000). A theoretical extension of the technology acceptance model: Four longitudinal field studies. Management Science 46 (2):186-204.

Venkatesh, V. and Bala, H. (2008). Technology acceptance model 3 and a research agenda on interventions. Decision Science 39 (2):273-312.

Deng, X. W. J., Doll, A. R., Hendrickson, and Scazzero, J. A. (2005), "A multi-group analysis of structural invariance: an illustration using the technology acceptance model," Information \& Management, vol. 42, pp. 745-759, 2005. 